\title{
Productivity and technological quality of sugarcane under fertilization of nitrogen and molybdenum
}

\author{
Renato Lemos dos Santos ${ }^{1}$, Fernando José Freire ${ }^{2 *}$, Emídio Cantídio Almeida de Oliveira ${ }^{2}$, \\ Djalma Euzébio Simões $\mathrm{Neto}^{3}$, Maércio Rodrigo Farias Amaral de Medeiros ${ }^{2}$, Patrícia da \\ Costa Bezerra ${ }^{2}$, Maria José Alves de Moura $^{1}$, José de Arruda Barbosa ${ }^{1}$, Nayara Rose da \\ Conceição Lopes ${ }^{1}$, Nayara de Lima Santos ${ }^{1}$
}

${ }^{l}$ Federal Institute of Education, Science and Technology of Pernambuco, Campus Vitória de Santo Antão, Propriedade Terra Preta, s/n, Zona Rural, C. P. 031, CEP 55602-970, Vitória de Santo Antão, PE, Brazil. 'Department of Agronomy, Federal Rural University, Dom Manoel de Medeiros street, s/n, Dois Irmãos, CEP 52171-900, Recife, PE, Brazil. ${ }^{3}$ Experimental Station of Sugarcane, Angela Cristina Canto Pessoa de Luna street, s/n, Santa Terezinha, CEP 55812-010, Carpina, PE, Brasil. *Corresponding author: fernando.freire@ufrpe.br

\begin{abstract}
The increase of $\mathrm{N}$ fertilization in sugarcane can negatively influence the technological quality of the crop for sugar and alcohol production. The use of Mo in fertilization combined with $\mathrm{N}$ can reduce this effect and increase agricultural and sugar yield. The objective of this study was to evaluate the levels of Mo in soil, roots and leaves of sugarcane fertilized with $\mathrm{N}$ and Mo, to measure agricultural and sugar productivity and to evaluate quality of the technological attributes for production of sugar and alcohol. Two varieties were cultivated (RB867515 and RB92579) under field conditions, submitted to two doses of $\mathrm{N}\left(0\right.$ and $\left.60 \mathrm{~kg} \mathrm{ha}^{-1}\right)$ and two doses of Mo (0 and $200 \mathrm{~g} \mathrm{ha}^{-1}$ ) both applied to the soil. The source of $\mathrm{N}$ used was urea and the source of Mo was sodium molybdate. RB867515 was influenced by Mo and agricultural and sugar productivity increased by $21 \%$. N fertilization did not increase agricultural productivity but reduced the technological quality of sugarcane, and Mo did not change this reduction. It is suggested that $\mathrm{N}$ fertilization should be reduced in first crop cycle and Mo fertilization should be stimulated.
\end{abstract}

Keywords: Availability of molybdenum, molybdenum nutrition, nitrogen nutrition, technological attributes for sugar and alcohol production 


\section{Introduction}

Sugarcane has been economically important for Brazil since the colonial period, the country is responsible for $33 \%$ of the world's production (CONAB, 2017), but it is a crop requiring high consumption of fertilizers, mainly $\mathrm{N}$.

$\mathrm{N}$ is the second macronutrient most absorbed by sugarcane, extracting about 94 to $260 \mathrm{~kg} \mathrm{ha}^{-1}$, varying with genotype, soil and fertilization (Oliveira et al., 2010). Despite the high uptake of $N$, the responses of the plant to $\mathrm{N}$ fertilization have been very varied. Azeredo et al. (1986) observed that in $80 \%$ of the cases, sugarcane in the first crop cycle (plant-cane) did not respond to $\mathrm{N}$ fertilization in evaluations carried out in 135 experiments in different regions of the country. However, Oliveira (2012) found an increase in agricultural productivity of sugarcane with increasing of $\mathrm{N}$ in three production environments in the Northeast of Brazil. Oliveira et al. (2013) also observed a positive variation of dry matter production of sugarcane in response to increase of $\mathrm{N}$, when the variety SP813250 was cultivated with doses of up to $120 \mathrm{~kg} \mathrm{ha}^{-1}$ of $\mathrm{N}$ in three soils of different producing areas in Brazil.

Sugarcane absorbs $\mathrm{N}$ of the soil in the ammoniacal $(\mathrm{N}-$ $\mathrm{NH}_{4}^{+}$) and nitrate $\left(\mathrm{N}-\mathrm{NO}_{3}^{-}\right)$forms, with predominance of the second form in aerated soils (Robinson et al., 2011). For the assimilation of $\mathrm{N}_{-} \mathrm{NO}_{3}^{-}$, it is necessary that Mo be available in the soil in adequate quantities, by the action of Mo as nitrate reductase (ARN) activity regulator (Nie et al., 2016), responsible for the first step of reducing $\mathrm{NO}_{3}^{-}$to $\mathrm{NH}_{4}^{+}$(Li-Ping et al., 2007). Li-Ping et al. (2007) observed that ARN in sugarcane was elevated by increasing the concentration of Mo in the nutrient solution, when the varieties RB72454 and RB7575 were grown under four Mo doses ( $0 ; 0.01$; 0.02; and $\left.0.04 \mathrm{mg} \mathrm{L}^{-1}\right)$. Therefore, Mo can affect the assimilation of $\mathrm{N}$ and influence the agricultural production and technological quality of sugarcane. Mo also regulates the activity of nitrogenase (AN). This enzyme in diazotrophic bacteria associated with sugarcane is responsible for the reduction of atmospheric $\mathrm{N}_{2}$ to $\mathrm{NH}_{3}$ and its assimilation in plants. $\mathrm{Li}$ Ping et al. (2007) evaluated the behavior of AN in sugarcane under the effect of increasing of Mo and found that despite the Mo application to raise AN, the increase in enzyme activity varied with the tissue and the genotype.

The low availability of Mo in the soil can reduce ARN, $\mathrm{AN}$ and $\mathrm{N}$ assimilation, reducing of agricultural productivity. The amount of Mo is low in most soils and the predominant anionic chemical form is molybdate, and its availability is influenced by chemical and mineralogical properties. For example, in high acid soils, nutrient availability is reduced (López et al., 2007). Elevation of a $\mathrm{pH}$ unit in a soil of $\mathrm{pH} 3$ can increase the availability of Mo by 100 times (Kaiser et al., 2005). An alternative to increase the Mo content available in the soil is the Mo fertilization. In areas where limestone application was not feasible, Brennan and Bolland (2007) observed that wheat yields were high when sowed on soils with $\mathrm{pH}$ higher than 4.3 in Australia. The availability of Mo can also be reduced by the presence of Fe and $\mathrm{Al}$ oxides (Vistoso et al., 2009).

Mo fertilization may be a viable alternative to increase Mo availability in tropical soils cultivated with sugarcane because of the naturally low $\mathrm{pH}$ values of these soils or the high amounts of $\mathrm{Fe}$ and $\mathrm{Al}$ oxides. Thus, well-nourished plants with Mo can be more efficient in the use of $\mathrm{N}$ by effect of the Mo on ARN and $\mathrm{AN}$, reducing the high $\mathrm{N}$ fertilization, without affecting agricultural and sugar productivity and the technological quality of sugarcane. 
The objective of this work was to evaluate the levels of Mo in soil, roots and leaves of sugarcane fertilized with $\mathrm{N}$ and $\mathrm{Mo}$, to measure the agricultural and sugar productivity and to evaluate the quality of the technological attributes for production of sugar and alcohol.

\section{Materials and Methods}

\subsection{Location and description of place of study}

The experiment was conducted in the Carpina Sugarcane Experiment Station (EECAC), in the Carpina municipality of Pernambuco, located at the geographic coordinates 7 $7^{\circ} 51^{\prime} 04^{\prime \prime} \mathrm{S}$ and $35^{\circ} 14^{\prime} 27^{\prime}$ 'W.

The municipality of Carpina has an altitude of $184 \mathrm{~m}$, with predominant As' climate, rainy tropical weather with dry summer, according to the Köppen system and average annual temperature of $24.2^{\circ} \mathrm{C}$ (Beltão et al., 2005). Rainfall during the experiment was 1,359 $\mathrm{mm}$ (Figure 1). In addition, three slides of $25 \mathrm{~mm}$ of water were applied in the first two months after planting, due to the low rainfall rates at the beginning of the experiment.

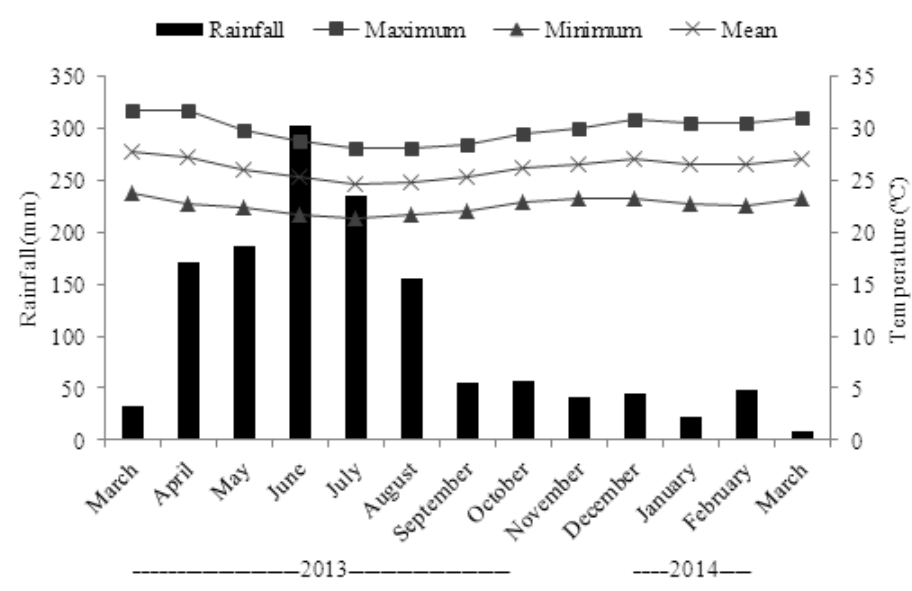

Figure 1. Rainfall during the trial at the Carpina Sugarcane Experiment Station, Carpina, Pernambuco, Brazil.

The soil of the experimental area was classified as Dystrophic Yellow Red Argisol (Santos et al., 2013). The chemical and physical characterization of the soil was performed in composite samples formed from the collection of 15 simple samples randomly collected and at two depths 0.0 to 0.2 and 0.2 to $0.4 \mathrm{~m}$ (Table 1). For the chemical characterization, the following were determined: the $\mathrm{pH}\left(\mathrm{H}_{2} \mathrm{O}\right), \mathrm{Ca}^{2+}, \mathrm{Mg}^{2+}, \mathrm{K}^{+}, \mathrm{Na}^{+}, \mathrm{Al}^{3+}$,
$(\mathrm{H}+\mathrm{Al}), \mathrm{P}, \mathrm{P}$ remaining (P-rem), Fe, Cu, Zn, Mn, Mo, $\mathrm{NH}_{4}^{+}, \mathrm{NO}_{3}^{-}$and TOC (Total Organic Carbon). Extraction of $\mathrm{Ca}^{2+}, \mathrm{Mg}^{2+}$ and $\mathrm{Al}^{3+}$ was realized with $1.0 \mathrm{~mol}$ $\mathrm{L}^{-1} \mathrm{KCl}$ and dosed cations by titulometry. Also, $\mathrm{P}$, $\mathrm{K}^{+}, \mathrm{Na}^{+}, \mathrm{Fe}, \mathrm{Cu}, \mathrm{Zn}, \mathrm{Mn}$ and Mo were extracted with Mehlich-1, with $\mathrm{P}$ and Mo dosed by colorimetry, $\mathrm{K}^{+}$ and $\mathrm{Na}^{+}$by flame photometry and $\mathrm{Fe}, \mathrm{Cu}, \mathrm{Zn}$ and $\mathrm{Mn}$ by spectrophotometry. Potential acidity $(\mathrm{H}+\mathrm{Al})$ was 
determined with $0.5 \mathrm{~mol} \mathrm{~L}^{-1}$ calcium acetate and titrated. TOC was determined by wet combustion with potassium dichromate and titration. All analyses were performed according to the methodologies described by Donagema et al. (2011).

Table 1. Chemical and physical soil attributes at different depths

\begin{tabular}{|c|c|c|}
\hline \multirow[t]{2}{*}{ Attribute } & \multicolumn{2}{|c|}{ Depth (m) } \\
\hline & $0.0-0.2$ & $0.2-0.4$ \\
\hline $\mathrm{pH}$ água $(1: 2,5)$ & 5.20 & 4.80 \\
\hline $\mathrm{Ca}^{2+}\left(\mathrm{cmol}_{\mathrm{c}} \mathrm{dm}^{-3}\right)$ & 2.10 & 1.80 \\
\hline $\mathrm{Mg}^{2+}\left(\mathrm{cmol}_{\mathrm{c}} \mathrm{dm}^{-3}\right)$ & 0.50 & 0.60 \\
\hline $\mathrm{K}^{+}\left(\mathrm{cmol}_{\mathrm{c}} \mathrm{dm}^{-3}\right)$ & 0.15 & 0.06 \\
\hline $\mathrm{Na}^{+}\left(\mathrm{cmol}_{\mathrm{c}} \mathrm{dm}^{-3}\right)$ & 0.04 & 0.07 \\
\hline $\mathrm{Al}^{3+}\left(\mathrm{cmol}_{\mathrm{c}} \mathrm{dm}^{-3}\right)$ & 0.50 & 0.70 \\
\hline$(\mathrm{H}+\mathrm{Al})\left(\mathrm{cmol}_{\mathrm{c}} \mathrm{dm}^{-3}\right)$ & 5.50 & 7.50 \\
\hline $\mathrm{P}\left(\mathrm{mg} \mathrm{dm} \mathrm{m}^{-3}\right)$ & 19.00 & 4.00 \\
\hline $\mathrm{Fe}\left(\mathrm{mg} \mathrm{dm}^{-3}\right)$ & 55.40 & 41.20 \\
\hline $\mathrm{Cu}\left(\mathrm{mg} \mathrm{dm}^{-3}\right)$ & 0.10 & 0.30 \\
\hline $\mathrm{Zn}\left(\mathrm{mg} \mathrm{dm}{ }^{-3}\right)$ & 2.50 & 2.40 \\
\hline $\operatorname{Mn}\left(\mathrm{mg} \mathrm{dm}^{-3}\right)$ & 6.60 & 5.00 \\
\hline $\operatorname{Mo}\left(\mathrm{mg} \mathrm{dm}^{-3}\right)$ & 0.14 & 0.15 \\
\hline $\operatorname{COT}\left(\mathrm{g} \mathrm{kg}^{-1}\right)^{(\mathrm{a})}$ & 1.19 & 1.25 \\
\hline $\mathrm{NO}_{3}^{-}\left(\mathrm{mg} \mathrm{dm}^{-3}\right)$ & 56.14 & 65.22 \\
\hline $\mathrm{NH}_{4}{ }^{+}\left(\mathrm{mg} \mathrm{dm}^{-3}\right)$ & 20.02 & 20.64 \\
\hline $\mathrm{CTC}_{\text {efetiva }}\left(\mathrm{cmol}_{\mathrm{c}} \mathrm{dm}^{-3}\right)^{(\mathrm{b})}$ & 3.29 & 3.23 \\
\hline $\mathrm{CTC}_{\text {potencial }}\left(\mathrm{cmol}_{\mathrm{c}} \mathrm{dm}^{-3}\right)^{(\mathrm{c})}$ & 8.29 & 10.03 \\
\hline $\mathrm{V}(\%)^{(\mathrm{d})}$ & 33.66 & 25.22 \\
\hline $\mathrm{m}(\%)^{(\mathrm{e})}$ & 15.20 & 21.67 \\
\hline Areia Total $\left(\mathrm{g} \mathrm{kg}^{-1}\right)$ & 723.00 & 681.00 \\
\hline Areia Grossa $\left(\mathrm{g} \mathrm{kg}^{-1}\right)$ & 509.80 & 481.20 \\
\hline Areia Fina $\left(\mathrm{g} \mathrm{kg}^{-1}\right)$ & 213.60 & 199.40 \\
\hline Silte $\left(\mathrm{g} \mathrm{kg}^{-1}\right)$ & 117.00 & 80.00 \\
\hline Argila $\left(\mathrm{g} \mathrm{kg}^{-1}\right)$ & 160.00 & 239.00 \\
\hline Ds $\left(\mathrm{kg} \mathrm{dm}^{-3}\right)^{(\mathrm{f})}$ & 1.46 & 1.41 \\
\hline $\operatorname{Dp}\left(\mathrm{kg} \mathrm{dm}^{-3}\right)^{(\mathrm{g})}$ & 2.56 & 2.47 \\
\hline PT $(\%)^{(h)}$ & 43.21 & 42.79 \\
\hline$\theta_{\mathrm{CC}}\left(\mathrm{Mg} \mathrm{Mg}^{-1}\right)^{(\mathrm{i})}$ & 0.12 & 0.13 \\
\hline$\theta_{\text {PMP }}\left(\mathrm{Mg} \mathrm{Mg}^{-1}\right)^{(\mathrm{j})}$ & 0.06 & 0.08 \\
\hline
\end{tabular}

${ }^{(a)}$ Total organic carbon; ${ }^{(b)}$ Effective cation exchange capacity; ${ }^{(c)}$ Potential cation exchange capacity; (d) Saturation by bases; ${ }^{(e)}$ Saturation by aluminum; ( ${ }^{(1)}$ Bulk density; ${ }^{(g)}$ Particules density; ${ }^{(\mathrm{h})}$ Total Porosidy; ${ }^{(\mathrm{i})}$ Field capacity; (j)Permanent wilting point. 
With the results of these chemical analyses, the saturation by bases $(\mathrm{V})$, the saturation by $\mathrm{Al}(\mathrm{m})$, the effective cation exchange capacity $\left(\mathrm{CEC}_{\text {effective }}\right)$ and the potential cation exchange capacity $\left(\mathrm{CEC}_{\text {potential }}\right)$ were calculated.

The $\mathrm{NH}_{4}^{+}$and $\mathrm{NO}_{3}^{-}$were extracted with $1.0 \mathrm{~mol} \mathrm{~L}-1$ $\mathrm{KCl}$ and dosed by steam distillation by the Kjedahl method, according to Tedesco et al. (1995).

Physically, the soil was characterized by granulometry, defining its textural class, soil density, density of particles, humidity in the field capacity $\left(\theta_{\mathrm{CC}}\right)$ and the permanent wilting point $\left(\theta_{\mathrm{PMP}}\right)$; hydraulic conductivity of saturated soil $\left(\mathrm{K}_{0}\right)$; and indirectly, the total porosity, using the determination of the densities. All the physical analyses were performed according to the methodology proposed by Donagema et al. (2011).

\subsection{Experimental field}

The sugarcane varieties RB92579 and RB867515 were used because they are widely cultivated in the Northeast of Brazil. The cultivation was submitted to two doses of $\mathrm{N}\left(0\right.$ and $\left.60 \mathrm{~kg} \mathrm{ha}^{-1}\right)$ and two doses of Mo $\left(0\right.$ and $\left.200 \mathrm{~g} \mathrm{ha}^{-1}\right)$, based on the study of the interaction of $\mathrm{N}$ and Mo fertilization in sugarcane developed by Oliveira (2012), using urea as source of $\mathrm{N}$ and sodium molybdate as Mo source. Fertilizers were applied in the furrow during the planting of sugarcane. Sodium molybdate was diluted in water and applied with the aid of a costal sprayer to facilitate fertilizer application and improve distribution in the planting groove.

The experimental design used was in randomized blocks, in a factorial arrangement of treatments (2 x $2 \times 2$ ), with four replications, totaling 32 experimental units. Each plot was comprised of seven grooves of $10 \mathrm{~m}$ in length, spaced by one meter, totaling $70 \mathrm{~m}^{2}$. The useful area was formed by the five central grooves, discarding a meter of the ends, totaling $40 \mathrm{~m}^{2}$.
The experiment started 40 days after the application of $2.45 \mathrm{Mg} \mathrm{ha}^{-1}$ of dolomitic limestone with total neutralization relative power (PRNT) of $89 \%$ in the total area and incorporated up to $0.2 \mathrm{~m}$ depth. The need for liming was calculated by the method of base saturation (Ribeiro et al., 1999), estimating an increase in saturation to $60 \%$. The fertilization was carried out in a foundation with the application of $\mathrm{P}$ and $\mathrm{K}$. Phosphate fertilization was performed considering the available $\mathrm{P}$ content and soil texture according to Simões Neto et al. (2011), with $60 \mathrm{~kg} \mathrm{ha}^{-1}$ of $\mathrm{P}_{2} \mathrm{O}_{5}$ being applied as triple superphosphate $\left(40 \% \mathrm{P}_{2} \mathrm{O}_{5}\right)$. The recommendation of $\mathrm{K}$ was based on the production expectation, estimating yields above $100 \mathrm{Mg} \mathrm{ha}^{-1}$ and using an average $\mathrm{K}_{2} \mathrm{O}$ efficiency of $1.4 \mathrm{~kg} \mathrm{Mg}^{-1}$ of sugarcane (Oliveira et al., 2010). Thus, $140 \mathrm{~kg} \mathrm{ha}^{-1}$ of $\mathrm{K}_{2} \mathrm{O}$ was applied as potassium chloride $\left(60 \% \mathrm{~K}_{2} \mathrm{O}\right)$. The planting of sugarcane varieties was carried out in grooves approximately $0.2 \mathrm{~m}$ deep and $14 \mathrm{Mg} \mathrm{ha}^{-1}$ of stems with seven months of age was distributed.

\subsection{Sampling of soil, roots and leaves}

Soil Mo contents were determined at 30, 70, 100, 130, 200 and 365 days after planting (DAP) at different stages of crop growth. Soil samples were collected in the useful area of the experimental plots at depths of 0.0 to $0.2 \mathrm{~m}$ and 0.2 to $0.4 \mathrm{~m}$. Soil sampling was performed approximately $0.25 \mathrm{~m}$ away from the planting line, and three simple samples were collected diagonally per plot for the formation of a composite sample. Subsequently, the collected soil samples were air dried, stripped and sieved in a $2 \mathrm{~mm}$ mesh sieve. The Mo was extracted with Mehlich-1 and dosed by colorimetry, according to Donagema et al. (2011).

The Mo was evaluated in leaves e roots of sugarcane. At 70, 100, 130, 200 and 365 DAP three leaves +1 were randomly collected (diagnostic leaf or index leaf) and one root portion per plot. The collected plant 
tissues were dried in a forced air circulation oven at $65^{\circ} \mathrm{C}$ and ground. To evaluate the Mo content, the tissues were digested in nitroperchloric solution and spectrophotometer determination was conducted, according to the methodology proposed by Silva (2009).

\subsection{Harvesting, agronomic evaluation and} technological quality of sugarcane

Sugarcane harvest was carried out with straw burning at 365 DAP and the agricultural productivity (stems per hectare - TCH) was evaluated. The productivity was measured by the weighting of the stalks with a dynamometer in the useful plot and the agricultural productivity per hectare was calculated as a function of the productivity obtained in the useful plot. Ten (10) stems were selected randomly in the useful plot to evaluate the technological attributes. The samples were ground in forage and sub-samples, according to the methodology suggested by CONSECANA (2006). The subsamples were submitted to the hydraulic press for one minute, under pressure of $250 \mathrm{~kg} \mathrm{~cm}^{-2}$, and the broth was collected and the following were determined: percentage of purity; total soluble solids ( $\left.{ }^{\circ} \mathrm{Brix}\right)$ with digital refractometer; percentage of apparent sucrose in the broth (Pol) using saccharimeter; and percentage of reducing sugars (AR).

The following were determined in the stem: percentage of fibers; percentage of sucrose in the stem (PC); and theoretical recoverable sugar (ATR). The variable fiber, Pol, purity and ATR were determined according to the methodology described by CONSECANA (2006). The yield of sugar or Pol per hectare $(\mathrm{TPH})$ was calculated by the equation: $\mathrm{TPH}=(\mathrm{TCH}$ $\times$ PC) $/ 100$, according to Lima Neto et al. (2013).

\subsection{Data analysis}

The levels of Mo in the soil, roots and leaves were evaluated as time-repeated measures. The statistical package SAS Learning 2.0 was used, following the procedure for mixed model, and the covariance test [AR(1), Ante (1), ARH (1), ARMA (1), CS, CSH, HF, TOEP, Lin (1), UN] which presented the lowest value of the Akaike criterion.

Regression analysis was performed as a function of time in the quantitative variables in which a significant effect $(P<0.05)$ was observed. The model that best represented the phenomenon was selected by the highest coefficient of determination $\left(\mathrm{R}^{2}\right)$ and the significance of the parameters was tested by the $\mathrm{t}$ test $(P<0.05)$. The data were submitted to analysis of variance (ANOVA), $\mathrm{F}$ test $(P<0.05)$ and Tukey test $(P<0.05)$ in the quantitative variables in which no significant effect was observed for regression.

The agricultural and sugar productivity and the technological attributes were evaluated according to the varieties of sugarcane as well as $\mathrm{N}$ and Mo fertilizations. Data were submitted to analysis of variance and the $\mathrm{F}$ test was performed $(P<0.05)$. The Tukey test $(P<0.05)$ was applied in variables in which the main effects and/or interaction were significant.

\section{Results}

\subsection{Mo content in soil}

The Mo content in the soil as a function of time was adjusted to the peak model (Figure 2A, B and C), except for the variety RB92579 fertilized with N, where the data adjusted to a linear model, when Mo (Figure 2D) was applied. When Mo was not applied, regardless of the application or not of $\mathrm{N}$, the data of the Mo content in the soil adjusted to a quadratic model (Figure 2). Mo levels in soil from 30 DAP decreased with 
$\mathrm{N}$ application in the variety RB867515 reduced the Mo content in the surface layer only in the absence of Mo fertilization (Figure 2B). The data of the Mo content in the soil were adjusted to a decreasing quadratic model and presented different minimum values in the absence of Mo fertilization (Figure 2A and B).

The Mo content in the soil was so low when the variety RB867515 was fertilized with N, that at 222 DAP no Mo was detected, whereas in treatment without $\mathrm{N}$, the Mo content was $0.04 \mathrm{mg} \mathrm{dm}^{-3}$. However, after reaching the minimum values, the Mo content increased until the end of the crop cycle (Figure 2A and B). Without Mo fertilization, the Mo content in the soil when the variety RB92579 was cultivated presented an inverse behavior to that of the variety RB867515. The low levels occurred in the absence of $\mathrm{N}$ (Figure 2C). However, Mo content was so low that it was not detected in both varieties when Mo was not applied.

The Mo contents were minimal at 190 and 260 DAP in the absence and presence of $\mathrm{N}$, respectively (Figure $2 \mathrm{C}$ and $\mathrm{D})$. When the variety received Mo fertilization, tion, the reduction of the Mo content was more accentuated with the $\mathrm{N}$ application (Figure 2D). Despite the decreasing linearity of Mo content with the application of the two nutrients, the lowest value was $0.06 \mathrm{mg} \mathrm{dm}^{-3}$ at $365 \mathrm{DAP}$ and not detected at 260 DAP, when RB92579 received only Mo fertilization (Figure 2C and D).

The Mo contents in the topsoil increased with fertilization up to 30 DAP. Subsequently, they were reduced to a minimum and then tended to increase, except when RB92579 was fertilized with N and Mo (Figure 2). The increase in Mo content of the soil was of $21 \%$ when RB867515 was cultivated without $\mathrm{N}$ fertilizer. When not fertilized with Mo, the Mo contents were reduced from the beginning of the cycle in this variety.

When the sugarcane varieties were not fertilized with Mo, a quadratic reduction of the Mo contents in the soil was observed after planting (Figure 2). In the absence of Mo fertilization, there was no increase of Mo content in the soil along the crop cycle, since the naturally available stock was being absorbed from the soil. 


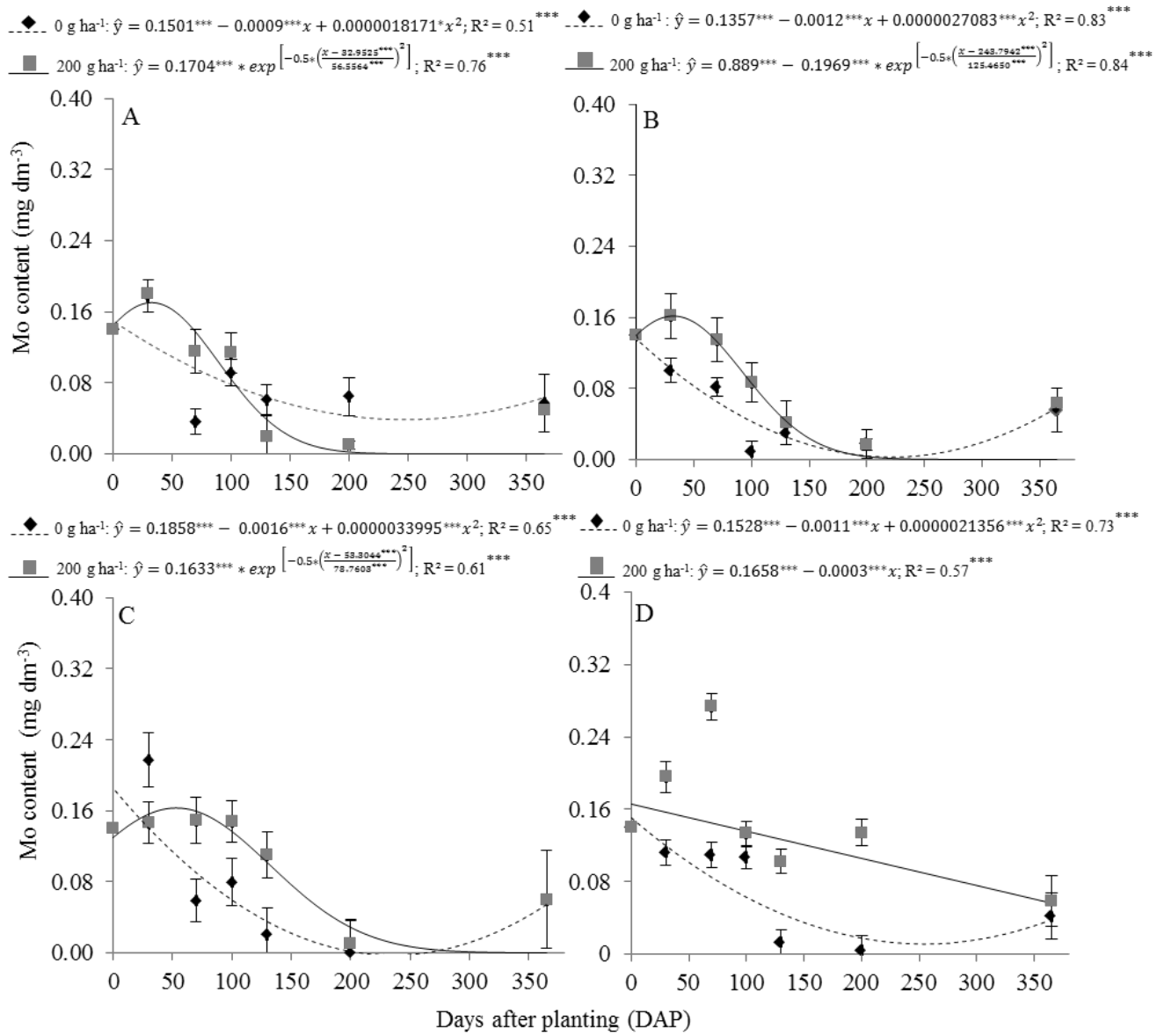

Figure 2. Mo content in the 0 to $0.2 \mathrm{~m}$ depth layer in soil cultivated with sugarcane in the first crop cycle (caneplant) at 0, 30, 70, 100, 130, 200 and 356 days after planting (DAP). (A) Variety RB867515 fertilized and not fertilized with Mo and fertilized with N; (B) Variety RB867515 fertilized and not fertilized with Mo and not fertilized with N; (C) Variety RB92579 fertilized and not fertilized with Mo and fertilized with N; (D) Variety RB92579 fertilized and not fertilized with Mo and not fertilized with N. 
In the subsurface layer ( 0.2 to $0.4 \mathrm{~m}$ depth), the behavior of the Mo content was similar to that of the surface layer, with increments after the Mo fertilization, followed by reduction. In the absence of Mo fertilization, there was a reduction of Mo contents throughout the crop cycle (Figure 3). However, Mo levels and their increments were higher with their supplementation, especially when the varieties were not fertilized with N (Figure 3).
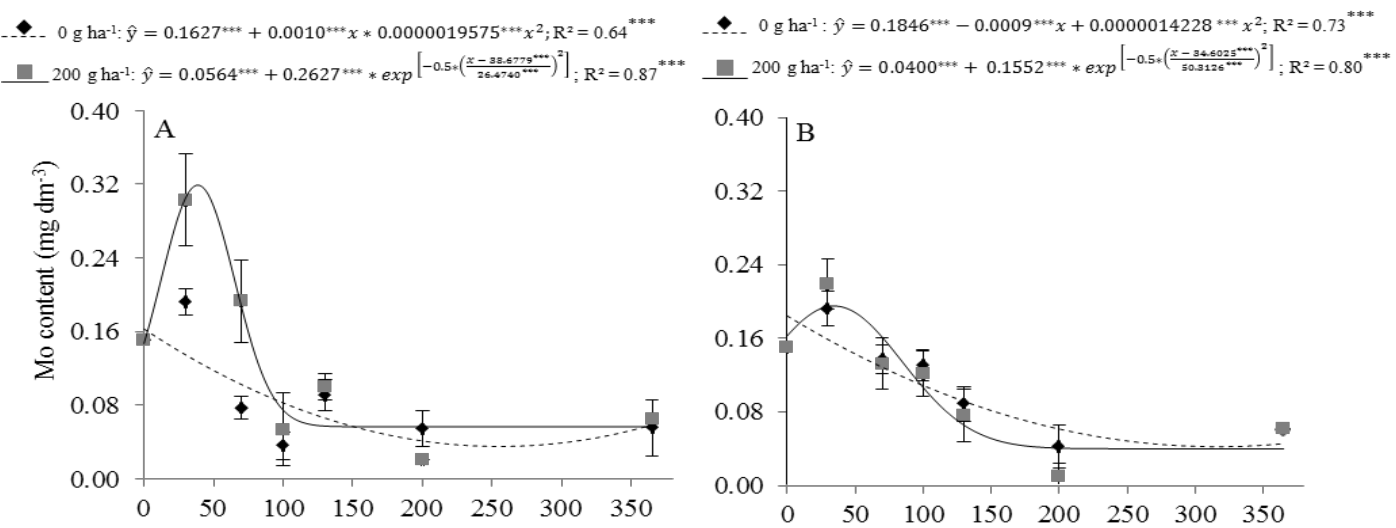

ـ. $0 \mathrm{~g} \mathrm{ha}^{-1}: \hat{y}=0.1669^{* * *}-0.0009^{* * *} x+0.0000015463^{* * *} x^{2} ; \mathrm{R}^{2}=0.64^{* * *}$

$200 \mathrm{~g} \mathrm{ha}^{-1}: \hat{y}=0.0410^{* *}+0.2127^{* *} * \exp \left[-0.5 *\left(\frac{x-48.418 * \cdots}{46.3983^{* * *}}\right)^{2}\right] ; \mathrm{R}^{2}=0.89^{* * *}$
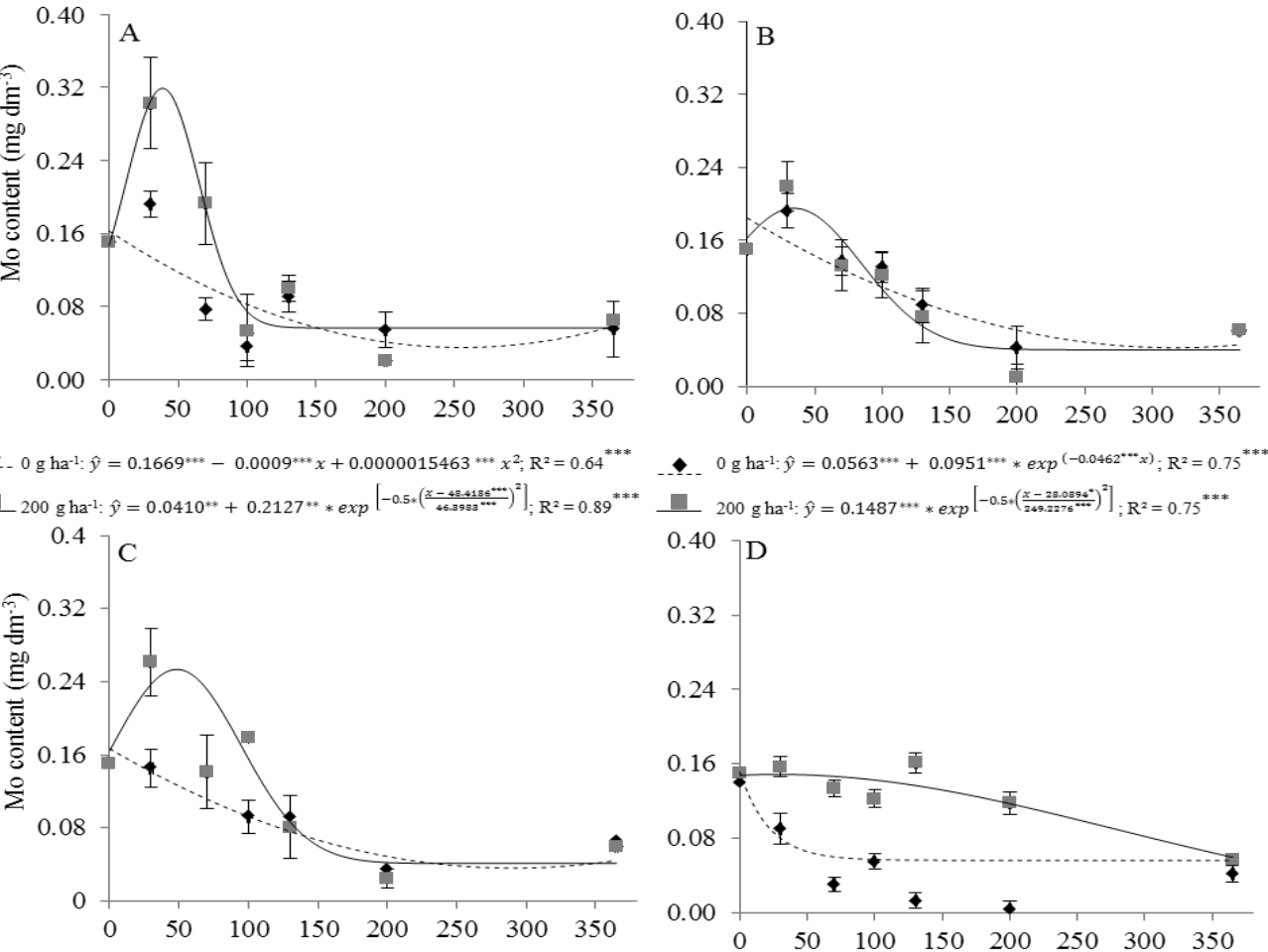

Days after planting (DAP)

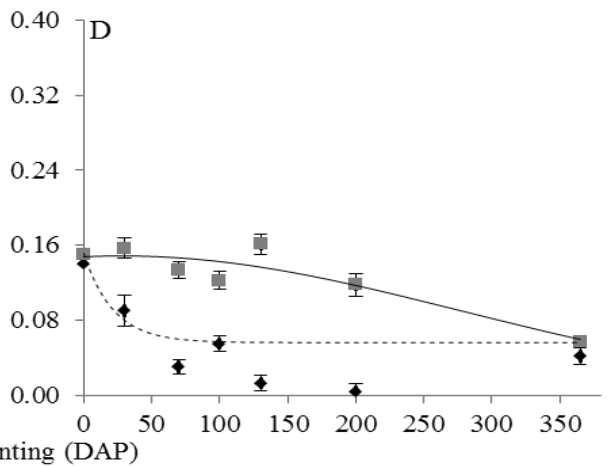

Figure 3. Mo content in the 0 to $0.4 \mathrm{~m}$ depth layer in soil cultivated with sugarcane in the first crop cycle (caneplant) at 0, 30, 70, 100, 130, 200 and 356 days after planting (DAP). (A) Variety RB867515 fertilized and not fertilized with Mo and fertilized with N; (B) Variety RB867515 fertilized and not fertilized with Mo and not fertilized with N; (C) Variety RB92579 fertilized and not fertilized with Mo and fertilized with N; (D) Variety RB92579 fertilized and not fertilized with Mo and not fertilized with N. 
In the cultivation of RB867515 and in the absence of $\mathrm{N}$ fertilization, the increase in soil Mo content in the subsurface layer was $0.17 \mathrm{mg} \mathrm{dm}-3$ and 0.05 $\mathrm{mg} \mathrm{dm}-3$ in the surface layer (Figure $2 \mathrm{~A}$ and $3 \mathrm{~A}$ ). The highest Mo increments in the subsurface layer were due to the mode of application of sodium molybdate, which was at the bottom of the planting groove of the sugarcane at approximately $0.2 \mathrm{~m}$ depth. In addition, the reduction of the Mo content in this layer was higher, occurring faster and in a shorter time than in the superficial layer.

The reduction of the Mo content in the subsurface layer of the soil by $\mathrm{N}$ fertilization was more intense, mainly with Mo fertilization. $\mathrm{N}$ application reduced the Mo content of the soil by $40 \%$ when the varieties were fertilized with Mo (Figure 3).

When not fertilized with Mo, the $\mathrm{N}$ application differentiated Mo levels from soil only of RB92579. Thus, the $\mathrm{N}$ application promoted a faster reduction of the Mo content in the subsurface layer, which stabilized at $0.05 \mathrm{mg} \mathrm{dm}^{-3}$, at 160 and 52 $\mathrm{DAP}$ in the absence and presence of $\mathrm{N}$ fertilization, respectively (Figure 3 ).

The Mo content of the soil in the subsurface layer was higher as a function of the Mo fertilization, independently of the $\mathrm{N}$ application and of the variety.
Differently from the surface layer where it was observed that the Mo contents tended to zero. In the subsurface layer, the contents were higher, with minimum values of $0.03 \mathrm{mg} \mathrm{dm}^{-3}$ of Mo (Figure 3).

\subsection{Mo content in leaf and root}

In general, Mo content in the roots of the sugarcane varieties were higher than in leaves, on average, from 0.58 to $0.97 \mathrm{mg} \mathrm{kg}^{-1}$ in the variety RB867515 and from 0.59 for $0.86 \mathrm{mg} \mathrm{kg}^{-1}$ in the RB92579 (Table 2). There was a concentration of Mo in the roots and a dilution of the nutrient in the aerial part, influenced by the greater production of biomass of leaves than of roots.

Mo content in the leaf of the varieties was not different, but in the roots the Mo content of the variety RB867515 was higher than in the RB92579 (Table 2).

In the leaf, the Mo content was not influenced by the $\mathrm{N}$ addition, although independent of the Mo application and the variety. However, in the roots there was an increase in this content with the $\mathrm{N}$ application. This increase in the Mo content with $\mathrm{N}$ addition was significant in roots, independent of the variety and Mo application (Table 2). 
Table 2. Mo content in the leaf and roots of the sugarcane varieties RB867515 and RB92579, with (w) and without (w/o) Mo application and with (w) and without (w/o) N application at 70, 100, 130, 200 and 356 days after planting (DAP)

\begin{tabular}{|c|c|c|c|c|c|c|c|c|}
\hline \multicolumn{9}{|c|}{ Leaf } \\
\hline \multirow{3}{*}{ Factor } & \multicolumn{4}{|c|}{ RB867515 } & \multicolumn{4}{|c|}{ RB92579 } \\
\hline & \multicolumn{2}{|c|}{ w/o-Mo } & \multicolumn{2}{|c|}{ w-Mo } & \multicolumn{2}{|c|}{ w/o-Mo } & \multicolumn{2}{|c|}{ w-Mo } \\
\hline & w/o- & w- & w/o- & W- & w/o- & W- & w/o- & W- \\
\hline DAP & & & & \multicolumn{3}{|c|}{$-\mathrm{mg} \mathrm{kg}^{-1}$} & \\
\hline 70 & 0.66 & 0.60 & 0.82 & 0.91 & 0.74 & 0.73 & 0.96 & 1.06 \\
\hline 100 & 0.37 & 0.37 & 0.43 & 0.40 & 0.36 & 0.38 & 0.44 & 0.45 \\
\hline 130 & 0.28 & 0.55 & 0.64 & 0.56 & 0.29 & 0.29 & 0.37 & 0.44 \\
\hline 200 & 0.68 & 0.82 & 0.96 & 0.93 & 0.77 & 0.78 & 0.83 & 1.06 \\
\hline 365 & 0.40 & 0.29 & 0.45 & 0.43 & 0.40 & 0.36 & 0.56 & 0.53 \\
\hline \multirow{3}{*}{$\begin{array}{l}\text { Mean N } \\
\text { Mean Mo } \\
\text { Mean }\end{array}$} & 0.48 & 0.53 & 0.66 & 0.65 & 0.51 & 0.51 & 0.63 & 0.71 \\
\hline & \multicolumn{2}{|c|}{$0.50 \mathrm{~b}$} & \multicolumn{2}{|c|}{$0.65 \mathrm{a}$} & \multicolumn{2}{|c|}{$0.51 \mathrm{~b}$} & \multicolumn{2}{|c|}{$0.67 \mathrm{a}$} \\
\hline & \multicolumn{4}{|c|}{$0.58 \mathrm{a}$} & \multicolumn{4}{|c|}{$0.59 \mathrm{a}$} \\
\hline \multicolumn{9}{|c|}{ Roots } \\
\hline \multirow{3}{*}{ Factor } & \multicolumn{4}{|c|}{ RB867515 } & \multicolumn{4}{|c|}{ RB92579 } \\
\hline & \multicolumn{2}{|c|}{ w/o-Mo } & \multicolumn{2}{|c|}{ w-Mo } & \multicolumn{2}{|c|}{ w/o-Mo } & \multicolumn{2}{|c|}{ w-Mo } \\
\hline & w/o- & w- & w/o- & W- & w/o- & W- & w/o- & W- \\
\hline DAP & & \multicolumn{3}{|c|}{$\mathrm{mg} \mathrm{kg}^{-1}$} & \\
\hline 70 & 0.98 & 1.15 & 1.30 & 1.26 & 0.79 & 0.76 & 1.13 & 1.16 \\
\hline 100 & 0.63 & 1.08 & 0.79 & 1.43 & 0.73 & 0.89 & 0.93 & 1.05 \\
\hline 130 & 0.99 & 1.05 & 1.21 & 1.00 & 0.69 & 0.83 & 0.49 & 1.13 \\
\hline 200 & 1.07 & 0.74 & 0.92 & 0.78 & 0.84 & 0.80 & 1.25 & 0.93 \\
\hline 365 & 0.81 & 0.63 & 0.85 & 0.75 & 0.48 & 0.70 & 0.70 & 0.90 \\
\hline Mean N & 0.90 & 0.93 & 1.01 & 1.04 & 0.71 & 0.80 & 0.90 & 1.03 \\
\hline Mean Mo & \multirow{2}{*}{\multicolumn{2}{|c|}{$0.91 \mathrm{~b}$}} & \multicolumn{2}{|c|}{$1.03 \mathrm{a}$} & \multicolumn{2}{|c|}{$0.75 \mathrm{~b}$} & \multirow{2}{*}{\multicolumn{2}{|c|}{$0.97 \mathrm{a}$}} \\
\hline Mean & & & \multicolumn{2}{|c|}{$0.97 \mathrm{a}$} & & & & \\
\hline
\end{tabular}

Equal lowercase letters in the line do not differ by Tukey test $(P<0.05)$.

\subsection{Agricultural productivity}

The effect of Mo fertilization on the yield of stalks and sugar depended of the variety. RB867515 res- ponded positively to the Mo application, with increases of $21 \%$ in the values of TCH and TPH, but the Mo fertilization did not increase yield in RB92579 (Figure 4). 

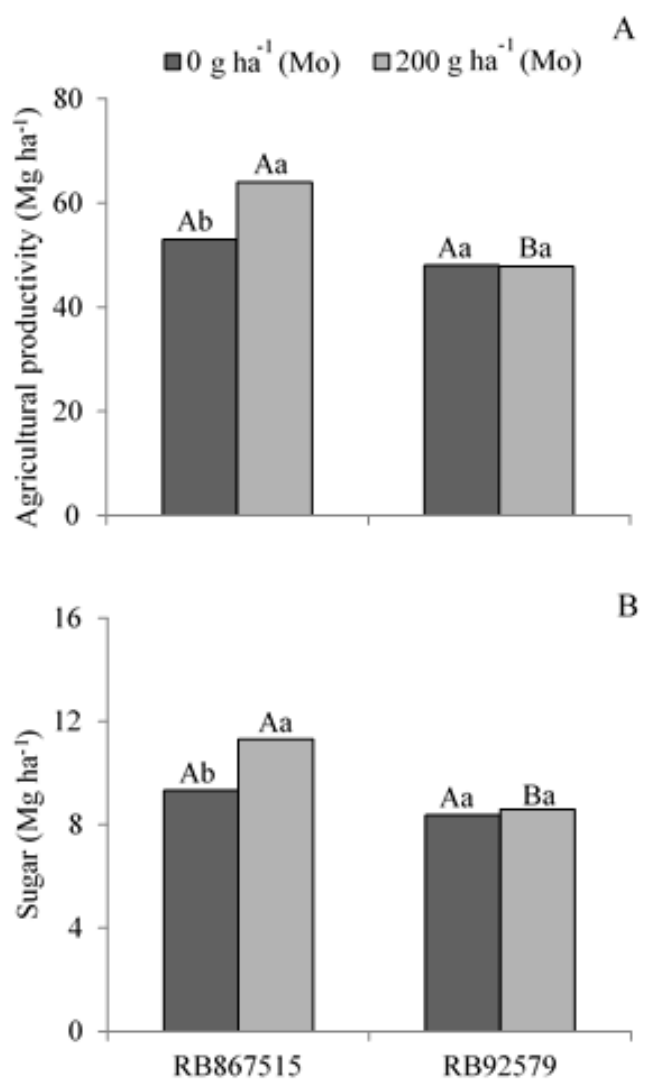

Figure 4. Agricultural productivity (A) and sugar (B) per hectare of the sugarcane varieties submitted the Mo application. Means in the same column followed by the same letter do not differ significantly by the Tukey test $(P \leq 0.05)$. Uppercase letters compare the varieties and lowercase letters compare the effect of Mo.

The yields of TCH e TPH of the varieties depended of the absence or presence of Mo. There was no difference in yields of the varieties when Mo was not applied. However, the yields of TCH and TPH in RB867515 with the Mo application were 34\% and $32 \%$ higher than in RB92579, respectively (Figure 4).
Therefore, it is recommended to use Mo fertilization in the fertility management of the variety RB867515, regardless of $\mathrm{N}$ fertilization. Additionally, $\mathrm{N}$ fertilization did not promote effect on the yields of the varieties, regardless of the Mo application (Figure 4). 


\subsection{Technological attributes of sugarcane for agri-} business

The purity of the sugarcane was not influenced by the Mo fertilization and the varieties, but it was reduced by the $\mathrm{N}$ application, regardless of the variety and $\mathrm{Mo}$ application (Figure 5).
The AR percentage varied by the Mo fertilization and there was the synergistic effect between the $\mathrm{N}$ application and the sugarcane varieties (Figure 5). The application of $200 \mathrm{~g} \mathrm{ha}^{-1}$ of Mo caused a deleterious effect on the AR percentage, but $\mathrm{N}$ fertilization on the variety $\mathrm{RB} 867515$ doubled the AR percentage. No differences were observed in the total soluble solids and Pol with the fertilizers application in the different varieties (Figure 5).
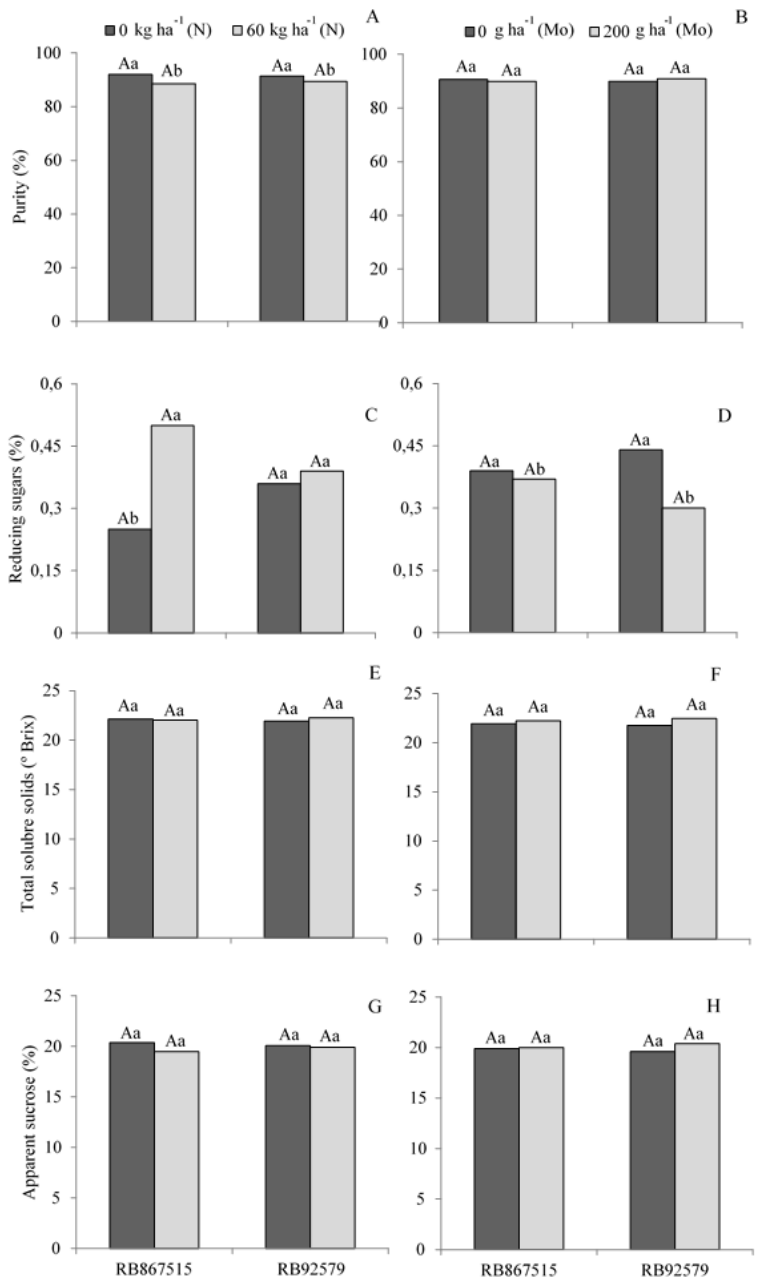

Figure 5. Purity (A and B), reducing sugars $(\mathrm{C}$ and $\mathrm{D})$, total soluble solids (E and F) and apparent sucrose (G and $\mathrm{H}$ ) of the sugarcane varieties submitted the combined application of $\mathrm{N}$ and Mo. Means in the same column followed by the same letter do not differ significantly by the Tukey test $(P \leq 0.05)$. Uppercase letters compare the varieties and lowercase letters compare the effect of Mo or N. 
No effects were observed for the $\mathrm{N}$ and Mo application on the fiber percentage in the different varieties (Figure 6).

The PC and ATR were influenced by the $\mathrm{N}$ application
(Figure 6). The application of $60 \mathrm{~kg} \mathrm{ha}^{-1}$ of $\mathrm{N}$ reduced the sugar percentage in both sugarcane varieties and the Mo fertilization not influenced to minimize this reduction.
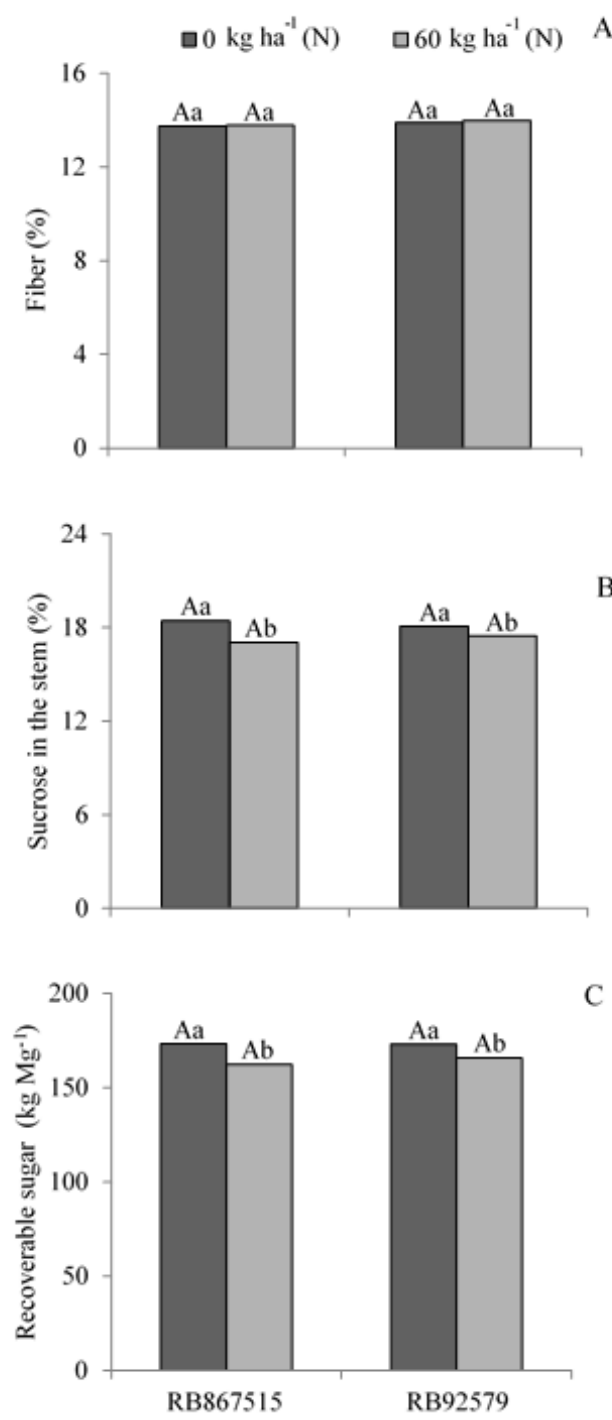

Figure 6. Fiber (A), sucrose in the stem (B) and recoverable theoretical sugar (C) of sugarcane varieties submitted the application of N. Means in the same column followed by the same letter do not differ significantly by the Tukey test $(P \leq 0.05)$. Uppercase letters compare the varieties and lowercase letters compare the effect of $\mathrm{N}$. 


\section{Discussion}

The soil Mo content in this study was linearly reduced with the cultivation time, when sugarcane was fertilized with $\mathrm{N}$ and Mo. Otto et al. (2009) observed that the $\mathrm{N}$ application in the planting of the variety SP813250 increased the root and shoot growth of sugarcane in Eutrophic Red-Yellow Latosol. Therefore, the increase of root biomass by $\mathrm{N}$ fertilization may have increased the Mo absorption in this study.

The reduction of Mo content in the soil surface layer cultivated with the variety RB867515 by $\mathrm{N}$ fertilization was due to higher Mo absorption. Oliveira et al. (2013) reported that $\mathrm{N}$ fertilization in RB867515 promoted an increase in shoot dry matter (MSPA) and Oliveira (2012) observed a higher Mo accumulation in sugarcane fertilized with N. However, Oliveira (2012) observed also that the application of doses up to $1,600 \mathrm{~g} \mathrm{ha}^{-1}$ of Mo promoted linear increases in the Mo content available from the soil.

The Mo content of the soil was increased up until 30 days after the application, because during that period there was no significant root growth and little or no Mo absorption (Jadoski et al., 2010). The sugarcane only 30 DAP initiates bud and root primordia emission. During this period, the plants utilizes stem reserves to meet their nutritional requirements (Jadoski et al., 2010). However, roots formed from this period absorbed Mo for assimilation of $\mathrm{N}-\mathrm{NO}_{3-}$, due their action in regulation of the nitrate reductase enzyme (Li-Ping et al., 2007; Nie et al., 2016). In fact, Mo levels in the soil were reduced from this period (Figure 2).

The decrease Mo content in soil was higher when the plants approached the phase of higher dry matter accumulation (Jadoski et al., 2010). The Mo absorption by the sugarcane varieties is mainly due to its role as an activator of the nitrate reductase enzyme.
The sugarcane tillering phase occurs from 40 to 120 DAP, when the aerial part begins to grow, with formation and elongation of the shoots up to 270 DAP (Jadoski et al., 2010). The $\mathrm{N}$ uptake by sugarcane in these two phases is high, and the second phase is responsible for the greatest nutrient accumulation (Silveira and Crocomo, 1990).

Thus, considering that there is predominance of $\mathrm{NO}_{3}$. to the detriment of $\mathrm{NH}_{4}+$ in the aerated soils (Amoo and Babalola, 2017), the plants absorb Mo for use

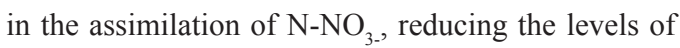
this micronutrient in the soil (Robinson et al., 2011). This reduction occurred up to 250 DAP in both Nfertilized varieties and in the absence of Mo (Figure 2). Subsequently, the Mo content increased in the soil surface layer because the absorption by the plants was reduced or ceased. Also, the increase Mo content in soil could be as a result of mineralization of the organic matter.

The highest levels of Mo with the Mo fertilization in the subsurface layer in relation to the superficial layer, occurred due to the application mode of the Mo. The Mo was sprayed in the stems that were planted at the bottom of the groove. In addition, the rapid reductions in Mo content in the subsurface layer can be explained by the higher density of positive charges to adsorb the molybdate anion, due to the $49 \%$ increase in the clay content in the subsurface layer in relation to the surface layer (Table 1).

The sugarcane stalks and $\mathrm{N}$ fertilizer were placed in grooves of $0.2 \mathrm{~m}$ depth in the plantation and soon after, there was heavy rainfall (Figure 1), and the Mo absorption was initially higher in the subsurface layer. Additionally, it is possible that $\mathrm{N}$ fertilization stimulated the root system of the sugarcane varieties to the subsurface layer, favoring a higher Mo absorption in this layer. 
We found in this study that the Mo content differed only in the roots of the varieties, with RB867515 being more cumulative than RB92579 (Table 2). This higher Mo absorption by RB867515, was due to its higher growth and biomass production.

The greatest Mo accumulation in variety RB867515 may have been due to some factors: larger root system, which allowed for greater soil exploration and, consequently, greater access to available Mo; greater metabolic capacity of nutrient absorption of the variety; higher $\mathrm{N}$ uptake in the nitrate form; higher $\mathrm{N}$-fixing capacity of the variety. There may have been a combination of more than one of these factors, making the RB867515 more Moaccumulating than RB92579.

In addition, Mo levels in the roots of the varieties indicated a Mo concentration in RB867515 and a dilution in RB92579. One hypothesis for this is that RB867515 has a lower translocation capacity, and accumulates Mo in the roots.

Mo contents were higher both in the leaf and in the roots when Mo was applied, regardless of the sugarcane variety and $\mathrm{N}$ application (Table 2), demonstrating the effectiveness Mo application. Brennan and Bolland (2007) cultivated wheat in the absence and presence of Mo fertilization in acid soils. According to the authors, when the wheat received the dose of $160 \mathrm{~g} \mathrm{ha}^{-1}$ of Mo, the grains produced presented an increase of $285 \%$ in the Mo content, corroborating the results of this work.

$\mathrm{N}$ fertilization promoted a greater growth of the root system (Otto et al., 2009), positively influencing Mo absorption, independent of its application. In the aerial part, although the $\mathrm{N}$ addition also promoted an increase in Mo contents, the enzymatic activity probably required more Mo, not allowing a significant effect of the $\mathrm{N}$ application in the Mo contents.

Mo Fertilization influenced agricultural and sugar productivity of the RB867515 more than RB92579. Santos (2014) reported that Mo stimulated the activity of the nitrate reductase enzyme in the RB867515 and had no effect on the enzyme activity in the RB92579. When the enzyme is more stimulated, there is an increase in $\mathrm{N}$ assimilation and increase of productivity. Few studies evaluated the yield of stems of different sugarcane varieties under the effect of Mo fertilization (Polidoro, 2001; Oliveira, 2012) and presented controversial results. Oliveira (2012) did not find a significant effect of Mo fertilization on sugarcane productivity. Polidoro (2001) reported an increase of $25 \%$ in shoot yield with the application of $400 \mathrm{~g} \mathrm{ha}^{-1}$ of Mo, corroborating the results of this study.

The agricultural productivity found in this study was low. Oliveira et al. (2011) studying nutritional efficiency in sugarcane varieties reported that the yields of the varieties RB867515 and RB92579 in the cane-plant without irrigation were of approximately $90 \mathrm{Mg}$ ha- 1 . The low productivity in both varieties was attributed to the low quality of the buds used in the planting and the competition with spontaneous herbs in the first two months of cultivation. During the cultivation of sugarcane of this study no was herbicides application due to its negative effect on the population of N-fixing bacteria (Silva et al., 2016). The competition with spontaneous herbs can decrease from three to four times the number of stems per linear meter and from six to seven times the productivity (Jadoski et al., 2010).

Mo fertilization increased the levels of Mo available in the soil (Figures 2 and 3), promoting a higher Mo absorption by RB867515 (Table 2), stimulating the extraction of N (Oliveira, 2012). The Mo increased assimilation of $\mathrm{N}^{-\mathrm{NO}_{3}}$, due to its acting as an activator of nitrate reductase (Li-Ping et al., 2007) and/or enhancing the biological $\mathrm{N}$ fixation by the participation of Mo in the nitrogenase responsible for the reduction of $\mathrm{N}_{2}$ to $\mathrm{NH}_{3}$ (Li-Ping et al., 2007), increasing the yield of stalks and sugar (Figure 4).

The increase in productivity promoted by $\mathrm{N}$ fertilization in the cane-plant cycle is controversial because 
to the higher source of $\mathrm{N}$ absorbed in this cycle not is mineral origin (Franco et al., 2011). However, there are studies that have shown antagonistic results. Franco et al. (2011), when evaluating aerial biomass in response to $\mathrm{N}$ fertilization in the cane-plant cycle, observed that the application of up to $120 \mathrm{~kg} \mathrm{ha}^{-1}$ of N did not promote increases in the variety SP81-3250 in Eutrophic Yellow Red Latosol. However, an increase of biomass was observed when the same variety was cultivated in dystrophic Red Latosol with application of up to $80 \mathrm{~kg} \mathrm{ha}^{-1}$ of $\mathrm{N}$.

Azeredo et al. (1986), in evaluations carried out in 135 experiments in different regions of Brazil, observed that in $80 \%$ of cases the cane-plant did not respond to $\mathrm{N}$ fertilization. Oliveira (2012), in a study carried out in three environments in northeastern Brazil, found a positive variation of shoot yield in the variety RB92579, as a response to the increase of N. $\mathrm{N}$ fertilization reduced the purity of sugarcane (Figure 5). However, they were not lower than the critical percentages recommended by the Sugarcane Producers Council in Brazil (CONSECANA, 2006). In accordance with quality standards, industrial units may refuse loading of sugarcane when the purity percentage of the broth is $<75 \%$ and in this study the values of purity were more high (Figure 5).

Tasso Júnior et al. (2007) evaluated the effect of different combinations of organic and mineral fertilization on the variety SP81-3250 and observed that the percentage of AR was $0.31 \%$ with the application of $120 \mathrm{~kg} \mathrm{ha}^{-1}$ of $\mathrm{N}$, much smaller than the effect of the application of $60 \mathrm{~kg} \mathrm{ha}^{-1}$ of $\mathrm{N}$ found in this study. RB867515 concentrated more sugar with the application of less N than SP81-3250.

Andrade et al. (2000) also did not found differences on total soluble solids and the percentage of Pol in the variety SP79-2233 with application of up to $200 \mathrm{~kg} \mathrm{ha}^{-1}$ of N. Oliveira et al. (2011) found that the total soluble solids and the percentage of $\mathrm{Pol}$ in the varieties RB867515 and RB92579 were 21.3 and $18.5 \%$, respectively. Therefore, the values are similar to those of this study. Fiber percentage of the sugarcane varieties in this study were higher than the industry recommendation. Oliveira et al. (2009) reported that the recommended range of fiber percentage should be from 10.5 to $12.5 \%$ for energy maintenance of the agribusiness units processing sugarcane.

$\mathrm{N}$ fertilization reduced the sugar percentage. However, the sucrose percentage found in this study was $16 \%$ higher than the observed by Tasso Júnior et al. (2007). The ATR values found in this study were higher than the found by Oliveira et al. (2011). These authors reported ATR values in the varieties RB867515 and RB92579 of 151 and $147 \mathrm{~kg} \mathrm{Mg}^{-1}$, respectively. These values were approximately $92 \%$ of the value found in this study with the application of $60 \mathrm{~kg} \mathrm{ha}^{-1}$ of $\mathrm{N}$ (Figure 6).

\section{Conclusions}

Mo fertilization promoted increase of Mo content in both the superficial and subsurface layers of the soil. The sugarcane variety RB867515 was influenced by the Mo fertilization and the agricultural and sugar yield were increased with the Mo application. $\mathrm{N}$ fertilization did not increase agricultural productivity and reduced the sucrose percentage and recoverable theoretical sugar, and Mo did not change this reduction. It is suggested that $\mathrm{N}$ fertilization should be reduced in this cultivation cycle, but Mo fertilization should be stimulated.

\section{Acknowledgement}

The authors would like to thank the National Council for Scientific and Technological Development (CNPq) for granting scholarships and to scholars and volunteers for their help in conducting the experiment and collecting data. This study was supported by Project CNPq No. 
471575 / 2009-7 titled "Evaluation of the availability of molybdenum for sugarcane and its contribution to nitrogen fertilization and nitrogen fixation".

\section{References}

Amoo, A.E., Babalola, O.O. 2017. Amonia-oxidizing microorganisms: key players in the promotion of plant growth. J. Soil Sci. Plant Nutr. 17, 935-947.

Andrade, L.A.B., Bocardo, M.R., Correa, J.B.D., Carvalho, G.J. 2000. Efeitos do nitrogênio aplicado nas formas fluída ou sólida em soqueira de canade-açúcar. Ciênc. Agrotec. 24, 516-520.

Azeredo, D.F., Bolsanello, J., Webwe, H., Vieira, J.R. 1986. Nitrogênio em cana-planta - doses e fracionamento. Stab. 4, 25-29.

Beltão, B.A., Mascarenhas, J.C., Miranda, J.L.F., Souza Júnior, L.C., Galvão, M.J., Pereira, S.N. 2005. Projeto cadastro de fontes de abastecimento por água subterrânea do Estado de Pernambuco: Diagnóstico do município de Carpina. Companhia de Pesquisa de Recuros Minerais-CPRM, Recife, 11 p.

Brennan, R.F., Bolland, M.D. 2007. Increased concentration of molybdenum in sown wheat seed decreases grain yield responses to applied molybdenum fertilizer in naturally acidic sandplain soils. J. Plant Nutr. 30, 2005-2019.

CONAB, Companhia Nacional de Abastecimento. 2017. Boletim cana. http://www.conab.gov.br/ OlalaCMS/uploads/arquivos/16-12-27-16-30-01boletim- cana-portugues-3o-lev-16-17.pdf (Accessed 10.04.2017).

CONSECANA, Conselho dos Produtores de Canade-açúcar, Açúcar e Álcool do Estado de São Paulo. 2006. Manual de instruções. CONSECANA, São Paulo, 112 p.

Franco, H.C.J., Otto, R., Faroni, C.E., Vitti, A.C., Oliveira, E.C.A., Trivelin, P.C.O. 2011. Nitrogen in sugarcane derived from fertilizer under Brazilian field conditions. Field Crop. Res. 121, 29-41.
Donagema, G.K., Campos, D.V.B.C., Calderano, S.B., Teixeira, W.G., Viana, J.H.M. 2011. Manual de métodos de análise de solos. Empresa Brasileira de Pesquisa Agropecuária - Embrapa, Rio de Janeiro, $230 \mathrm{p}$.

Jadoski, C.J., Toppa, E.V.B., Julianetti, A., Hulshof, T., Ono, E.O., Rodrigues, J.D. 2010. Fisiologia do desenvolvimento do estádio vegetativo da canade-açúcar (Saccharum officinarum). Pesqui. Apl. Agrotec. 3, 169-176.

Kaiser, B.N., Gridley, K.L., Brady, J.N., Phillips, T., Tyerman, S.D. 2005. The role of molybdenum in agricultural plant production. Ann. Bot. 96: 745-754.

Lima Neto, J.F., Dutra Filho, J.A., Simões Neto, D.E., Silva, A.E.P., Silva, L.J., Ferreira, G.E. 2013. Avaliação agroindustrial e parâmetros genéticos de clones UFRPE de cana-de-açúcar no litoral norte de Pernambuco. Pesq. agropec. pernamb. 18,: 8-13.

Li-Ping, W., Yang-Rui, L., Li-Tao, Y. 2007. Effects of molybdenum on nitrogen metabolism of sugarcane. Sugar Tech. 9, 36-42.

López, R.S., Alvear, M., Gianfreda, L., Mora, M.L. 2007. Molybdenum availability in Andisols and Its effect on biological parameters of soil and red clover (Trifolium Pratense L.). Soil Sci. 172, 913-924.

Nie, Z., Hu, C., Tan, Q., Sun, X. 2016. Gene expression related to molybdenum enzyme biosynthesis in response to molybdenum deficiency in winter wheat. J. Soil Sci. Plant Nutr. 16, 979-990.

Oliveira, A.C. 2012. Interação da adubação nitrogenada e molíbdica em cana-de-açúcar. Doctoral Thesis, Universidade Federal Rural de Pernambuco, Brasil, 96 p.

Oliveira, E.C.A., Freire, F.J., Oliveira, A.C., Simões Neto, D.E., Rocha, A.T., Carvalho, L.A. 2011. Produtividade, eficiência de uso da água e qualidade tecnológica de cana-de-açúcar submetida a diferentes regimes hídricos. Pesqui. Agropecu. Bras. 446, 617-625. 
Oliveira, E.C.A., Freire, F.J., Oliveira, R.I., Freire, M.B.G.S., Simões Neto, D.E., Silva, S.A.M. 2010. Extração e exportação de nutrientes por variedades de cana-de-açúcar cultivadas sob irrigação plena. Rev. Bras. Cienc. Solo. 34, 1343-1352.

Oliveira, E.C.A., Gava, G.J.C., Trivelin, P.C.O., Otto, R., Franco, H.C.J. 2013. Determining a critical nitrogen dilution curve for sugarcane. J. Plant Nutr. Soil Sci. 176, 712-723.

Oliveira, E.L., Andrade, L.A.B., Faria, M.A., Evangelista, A.W.P., Morais, A.R. 2009. Uso de vinhaça de alambique e nitrogênio em cana-de-açúcar irrigada e não irrigada. Pesqui. Agropecu. Bras. 44: 1398-1403.

Otto, R., Franco, H.C.J., Faroni, C.E., Vitti, A.C., Trivelin, P.C.O. 2009. Fitomassa de raízes e da parte aérea da cana-de-açúcar relacionada à adubação nitrogenada de plantio. Pesqui. Agropecu. Bras. 44, 398-405.

Polidoro, J.C. 2001. O molibdênio na nutrição nitrogenada e na contribuição da fixação biológica de nitrogênio associada a cultura da cana-de-açúcar. Doctoral Thesis, Universidade Federal Rural do Rio de Janeiro, Brasil, 185 p.

Ribeiro, A.C., Guimarães, P.T.G., Alvarez, V.V.H 1999. Recomendações para o uso de corretivos e fertilizantes em Minas Gerais: 5 ${ }^{\mathrm{a}}$ Aproximação. Comissão de Fertilidade do Solo do Estado de Minas Gerais, Viçosa, 359 p.

Robinson, N., Brackin, R., Vinall, K., Soper, F., Holst, J., Gamage, H., Paungfoo-Lonhienne, C., Rennenberg, H., Lakshmanan, P., Schmidt, S. 2011. Nitrate paradigm does not hold up for sugarcane. PLoS One. 6, e19045.

Santos, H.G., Jacomine, P.K.T., Anjos, L.H.C., Oliveira, V.A., Lumbreras, J.F., Coelho, M.R., Almeida, J.A., Cunha, T.J.F., Oliveira, J.B. 2013. Sistema Brasileiro de Classificação de Solos. Empresa
Brasileira de Pesquisa Agropecuária - Embrapa, Brasília, 353 p.

Santos, R.L. 2014. Molibdênio no metabolismo e na fixação biológica de nitrogênio em cana-de-açúcar. Doctoral Thesis, Universidade Federal Rural de Pernambuco, Brasil, 135 p.

Silva, F.C. 2009. Manual de análises químicas de solos, plantas e fertilizantes. Empresa Brasileira de Pesquisa Agropecuária - Embrapa, Brasília, 627 p.

Silva, M.O., Freire, F.J., Kuklinky-Sobral, J., Oliveira, E.C.A., Freire, M.B.G.S., Apolinário, V.X.O 2016. Bacteria associated with sugarcane in Northeastern Brazil. Afr. J. Microbiol. Res. 10 1586-1594.

Silveira, J.A.G., Crocomo, O.J. 1990. Assimilação de nitrogênio em cana-de açúcar cultivada em presença de elevado nível de nitrogênio e de vinhaça no solo. Bras. J. Plant Physiol. 2, 7-15.

Simões Neto, D.E., Oliveira, A.C., Rocha, A.T., Freire, F.J., Freire, M.B.G.S., Nascimento, C.W.A. 2011. Níveis críticos de fósforo em solos cultivados com cana-de-açúcar em Pernambuco. Rev. Ceres. 58, 802-810.

Tasso Júnior, L., Marques, M.O., Franco, A., Nogueira, G.A., Nobile, F.O., Camilotti, F., Silva, A.R. 2007. Produtividade e qualidade de cana-de-açúcar cultivada em solo tratado com lodo de esgoto, vinhaça e adubos minerais. Eng. Agríc. 27, 276-283.

Tedesco, M.J., Gianello, C., Bissani, C.A., Bohnen, H., Volkweis, S.J. 1995. Análises de solos, plantas e outros materiais. Editora Universitária da Universidade Federal do Rio Grande do Sul, Porto Alegre, $174 \mathrm{p}$.

Vistoso, G.E.M.V., Bolan, N.S., Theng, B.K.G., Mora, M.L. 2009. Kinetics of molybdate and phosphate sorption by some chilean andisols. J. Soil Sci. Plant Nutr. 9, 55-68. 